\title{
Sulforaphane inhibits hypoxia-induced HIF-1 $\alpha$ and VEGF expression and migration of human colon cancer cells
}

\author{
DONG HWAN KIM, BOKYUNG SUNG, YONG JUNG KANG, SEONG YEON HWANG, \\ MIN JEONG KIM, JEONG-HYUN YOON, EUNOK IM and NAM DEUK KIM \\ Department of Pharmacy, Molecular Inflammation Research Center for Aging Intervention, \\ Pusan National University, Busan 46241, Republic of Korea
}

Received June 14, 2015; Accepted September 22, 2015

DOI: $10.3892 /$ ijo.2015.3200

\begin{abstract}
The effects of sulforaphane (a natural product commonly found in broccoli) was investigated on hypoxia inducible factor- $1 \alpha$ (HIF-1 $\alpha$ ) expression in HCT116 human colon cancer cells and AGS human gastric cancer cells. We found that hypoxia-induced HIF-1 $\alpha$ protein expression in HCT116 and AGS cells, while treatment with sulforaphane markedly and concentration-dependently inhibited HIF-1 $\alpha$ expression in both cell lines. Treatment with sulforaphane inhibited hypoxia-induced vascular endothelial growth factor (VEGF) expression in HCT116 cells. Treatment with sulforaphane modulated the effect of hypoxia on HIF-1 $\alpha$ stability. However, degradation of HIF-1 $\alpha$ by sulforaphane was not mediated through the $26 \mathrm{~S}$ proteasome pathway. We also found that the inhibition of HIF-1 $\alpha$ by sulforaphane was not mediated through AKT and extracellular signal-regulated kinase phosphorylation under hypoxic conditions. Finally, hypoxiainduced HCT116 cell migration was inhibited by sulforaphane. These data suggest that sulforaphane may inhibit human colon cancer progression and cancer cell angiogenesis by inhibiting HIF- $1 \alpha$ and VEGF expression. Taken together, these results indicate that sulforaphane is a new and potent chemopreventive drug candidate for treating patients with human colon cancer.
\end{abstract}

\section{Introduction}

Hypoxic conditions are associated with increased tumor growth and metastasis, as well as poor survival in cancer patients (1). Hypoxia inducible factor- $1 \alpha$ (HIF- $1 \alpha)$ is a key protein that is expressed under hypoxic conditions and promotes vascular remodeling by vascular endothelial growth factor (VEGF). VEGF is one of the most critical factors that stimulate

Correspondence to: Professor Eunok Im or Professor Nam Deuk Kim, Department of Pharmacy, College of Pharmacy, Pusan National University, Busandaehag-ro, 63 beon-gil 2, Geumjeong-gu, Busan 46241, Republic of Korea

E-mail: eoim@pusan.ac.kr

E-mail: nadkim@pusan.ac.kr

Key words: sulforaphane, colon cancer cells, HIF-1, vascular endothelial growth factor angiogenesis. Therefore, inhibition of HIF-1 $\alpha$ and VEGF has demonstrated therapeutic efficacy in the treatment of several types of cancer. Expression of VEGF is regulated by hypoxia, growth factors, and oncogenes (2). HIF-1 is a heterodimeric transcription factor composed of HIF-1 $\alpha$ and aryl hydrocarbon receptor nuclear translocator (ARNT, HIF-1 $\beta$ ), which translocates to the nucleus and binds to hypoxia response element (HRE) binding sites. Under normoxic conditions, HIF-1 $\alpha$ protein is efficiently degraded by the ubiquitin protein ligase Von Hippel-Lindeau (VHL) and thus does not exert its effects (3). Several compounds have been tested as inhibitors of hypoxia-induced HIF-1 $\alpha$ expression in cancer cells (4-6).

Various natural products and their analogues are currently being researched as chemopreventive agents (7-9). Sulforaphane is a potent isothiocyanate derivative found in broccoli and other vegetables, such as Brussels sprouts and cabbage, and has various health benefits, including anticancer and antioxidant properties $(8,10)$. Many studies have revealed that sulforaphane activates phase 2 antioxidant enzymes via nuclear factor E2-related factor 2 (Nrf2) (11-14). In the last decade, many studies revealed that sulforaphane acts as a chemopreventive agent by inducing apoptosis and cell cycle arrest and inhibiting proliferation. In colon cancer cells, sulforaphane induced apoptosis and G2/M phase cell cycle arrest (15-19). In vivo studies showed that sulforaphane suppressed azoxymethane-induced colonic aberrant crypt foci (ACF) (20) and prevented polyps in Apc/Min mice (21).

Previous studies using hypoxic conditions revealed that sulforaphane inhibited expression of HIF-1 $\alpha$ in human tongue squamous cancer cells and prostate cancer cells (7). However, the mechanisms by which sulforaphane inhibits HIF-1 $\alpha$ in colon cancer cells under hypoxic conditions are not well understood.

In this study, we investigated the effects of sulforaphane on expression of HIF- $1 \alpha$ and VEGF, as well as migration under hypoxic conditions, in human colon cancer cells.

\section{Materials and methods}

Chemicals. Sulforaphane was purchased from Sigma-Aldrich Co. (St. Louis, MO, USA) and dissolved at a concentration of $100 \mathrm{mM}$ in dimethyl sulfoxide (DMSO) as a stock solution, which was stored $-20^{\circ} \mathrm{C}$. The stock solution was diluted with cell 
culture medium to the desired concentration prior to use. The maximum concentration of DMSO did not exceed $0.1 \%(\mathrm{v} / \mathrm{v})$, a concentration at which DMSO did not influence cell growth (data not shown). The selective proteasome inhibitor MG132 and protein synthesis inhibitor cycloheximide ( $\mathrm{CHX}$ ) were purchased from Sigma-Aldrich.

Cell culture. HCT116 human colon cancer cells and AGS human gastric cancer cells were obtained from American Type Culture Collection (ATCC, Manassas, VA, USA). Cells were maintained in RPMI-1640 medium (Hyclone, Logan, UT, USA) in a humidified atmosphere of $5 \% \mathrm{CO}_{2}$ at $37^{\circ} \mathrm{C}$. The RPMI-1640 medium was supplemented with $10 \%$ heat-inactivated fetal bovine serum (FBS, Hyclone), $2 \mathrm{mM}$ glutamine (Sigma-Aldrich), $100 \mathrm{U} / \mathrm{ml}$ penicillin (Hyclone), and $100 \mu \mathrm{g} / \mathrm{ml}$ streptomycin (Hyclone).

Hypoxia experiments. Experiments to investigate the effects of hypoxia were carried out in the hypoxia chamber of an anaerobic system (Thormo, Marietta, OH, USA). The hypoxic condition was $1 \% \mathrm{O}_{2}$ and $5 \% \quad \mathrm{CO}_{2}$. The temperature was maintained at $37^{\circ} \mathrm{C}$. The normoxic condition was $21 \% \mathrm{O}_{2}$ and $5 \% \mathrm{CO}_{2}$ (in a standard $\mathrm{CO}_{2}$ incubator). For hypoxia experiments, HCT116 and AGS cells were grown to $50 \%$ confluence in a standard $\mathrm{CO}_{2}$ incubator at $37^{\circ} \mathrm{C}$. Twenty-four hours prior to the experiment, cell culture media were placed in normoxic and hypoxic chambers to allow equilibration. Immediately before each experiment, cell culture media were withdrawn from HCT116 and AGS cells and replaced with fresh media that were equilibrated to normoxic and hypoxic conditions for $24 \mathrm{~h}$.

MTT assay. Cell survival was quantified by an MTT (3-(4,5-dimethylthiazol-2-yl)-2,5-diphenyltetrasolium bromide; Sigma-Aldrich) assay to measure mitochondrial activity in viable cells. Cells seeded at a density of $1 \times 10^{5}$ per well were allowed to adhere overnight, after which the culture media were replaced with fresh media. Cells were exposed to sulforaphane at concentrations of $12.5,25$ and $50 \mu \mathrm{M}$ for $6 \mathrm{~h}$ under normoxic and hypoxic conditions. The control groups were treated with DMSO equal to the highest percentage $(<0.1 \%)$ used in the experimental conditions for the MTT assay. After $6 \mathrm{~h}$, the medium was replaced. MTT was freshly prepared at a concentration of $5 \mathrm{mg} / \mathrm{ml}$ in PBS and passed through a filter (pore size, $0.2 \mu \mathrm{m}$ ). An aliquot of $2 \mathrm{ml}$ of MTT stock solution was added to each well and the plate was incubated at $37^{\circ} \mathrm{C}$ for $4 \mathrm{~h}$ in a humidified $5 \% \mathrm{CO}_{2}$ atmosphere. After $2 \mathrm{~h}$, media were removed. To each well, $2 \mathrm{ml}$ of DMSO was added in order to solubilize the formazan crystals, which were measured after $10 \mathrm{~min}$. The optical density of each well was measured with a spectrophotometer equipped with a 540-nm filter.

Protein preparation and western blot analysis. Cells were harvested and washed twice in PBS at $4^{\circ} \mathrm{C}$. Total cell lysates were lysed in lysis buffer [40 mM Tris (pH 8.0), $120 \mathrm{mM} \mathrm{NaCl}$, $0.5 \% \mathrm{NP}-40,0.1 \mathrm{mM}$ sodium orthovanadate, $2 \mu \mathrm{g} / \mathrm{ml}$ aprotinin, $2 \mu \mathrm{g} / \mathrm{ml}$ leupeptin and $100 \mu \mathrm{g} / \mathrm{ml}$ phenymethylsulfonyl fluoride (PMSF)]. The supernatants were collected and protein concentrations were measured with protein assay reagents (Pierce, Rockford, IL, USA). Equal amounts of protein were denatured by boiling at $100^{\circ} \mathrm{C}$ for $5 \mathrm{~min}$ in sample buffer $(0.5 \mathrm{M}$ Tris- $\mathrm{HCl}$, $\mathrm{pH} 6.8,4 \%$ sodium dodecyl sulfate (SDS), $20 \%$ glycerol, $0.1 \%$ bromophenol blue, $10 \% \beta$-mercaptoethanol) at a 1:1 ratio. Equal amount of the total proteins were subjected to $6-15 \%$ SDS-polyacrylamide gel electrophoresis and transferred to polyvinylidene difluoride membranes. The membranes were blocked with $5 \%$ non-fat dry milk in Tris-buffered saline with Tween-20 buffer (TBS-T) (20 mM Tris, $100 \mathrm{mM} \mathrm{NaCl}$, $\mathrm{pH} 7.5$, and $0.1 \%$ Tween-20) for $1 \mathrm{~h}$ at room temperature, after which the membranes were incubated overnight at $4^{\circ} \mathrm{C}$ with the primary antibodies. The membranes were washed thrice for 10 min with TBS-T buffer and incubated for $1 \mathrm{~h}$ with horseradish peroxidase-conjugated anti-rabbit or anti-mouse immunoglobin (Santa Cruz Biotechnology Inc., Santa Cruz, CA, USA). The membranes were washed 4 times for $10 \mathrm{~min}$ with TBS-T buffer. Antigen-antibody complexes were detected using the enhanced chemiluminescence (ECL) detection system (GE Healthcare Biosciences, Pittsburgh, PA, USA).

ELISA assay. To analyze VEGF secretion, HCT116 cells were seeded in 12-well plates, cultured to $50 \%$ confluence, pretreated with sulforaphane or DMSO (control treatment) for $30 \mathrm{~min}$, and switched to fresh media that were pre-conditioned in normoxic or hypoxic conditions. Cells were incubated with or without sulforaphane at the corresponding conditions for $24 \mathrm{~h}$. The supernatants in the wells were collected, cleared by centrifugation, and stored at $-20^{\circ} \mathrm{C}$. ELISA was performed using the human VEGF Quantikine kit (R\&D Systems, Minneapolis, MN, USA) according to the manufacturer's protocol. Recombinant human VEGF was used for calibration. Experiments were carried out at least 3 times in triplicate.

In vitro migration assay. Cell migration assays were performed using 24-well modified Boyden chambers (Corning Life Science, Corning, NY, USA). A cell migration kit was used for the cell migration assay according to the manufacturer's protocol. Confluent cells were added to the inner chamber of the insert in $100 \mu \mathrm{l}$ of serum-free medium. Medium $(600 \mu \mathrm{l})$ with $10 \%$ FBS was added to the lower chamber. To determine the effect of sulforaphane on cell migration, 5 or $10 \mu \mathrm{M}$ sulforaphane was added to the lower chamber (DMSO was used as a control). Cells were fixed and stained with the DiffQuick Stain kit (Baxter, McGaw Park, IL, USA) following the procedure described by the manufacturer. The number of migrating cells was counted under a microscope (x200 magnification) and the results were expressed as the percentage of invaded cells per field for each condition.

Statistical analysis. Results are expressed as the mean \pm SD of 3 separate experiments. Data were analyzed by Student's $\mathrm{t}$-test. Means were considered significantly different at $\mathrm{p}<0.05$ or $\mathrm{p}<0.01$.

\section{Results}

Sulforaphane inhibits hypoxia-induced HIF-1a in HCT116 and AGS cells. To investigate the effects of hypoxia-induced HIF-1 $\alpha$, HCT116 and AGS cells were grown to $70 \%$ confluence in a standard $\mathrm{CO}_{2}$ incubator at $37^{\circ} \mathrm{C}$ (normoxic conditions of $21 \% \mathrm{O}_{2}$ and $5 \% \mathrm{CO}_{2}$ ) and transferred to a hypoxia chamber 
A

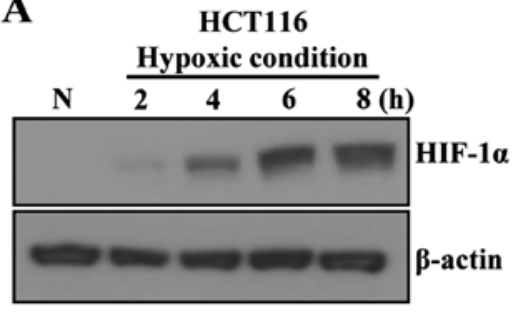

B

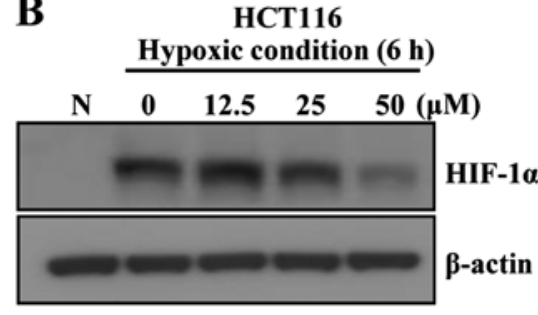

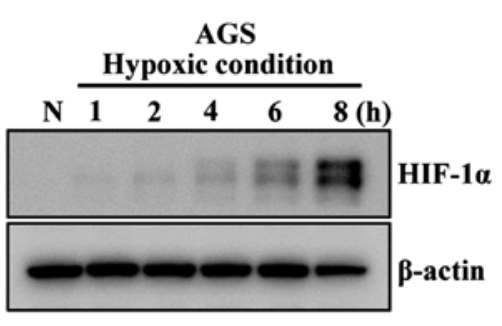

AGS

Hypoxic condition $(8 \mathrm{~h})$

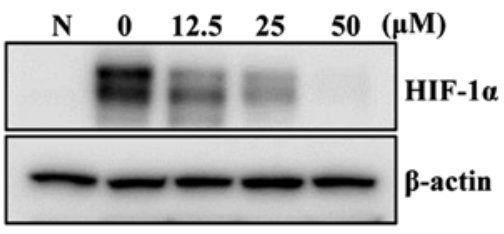

Figure 1. Effects of sulforaphane on HIF-1 $\alpha$ protein expression under hypoxic conditions in HCT116 and AGS cells. (A) Both cell lines were incubated for various time periods in a hypoxic chamber, in which cells were exposed to $1 \% \mathrm{O}_{2}$. (B) Both cell lines were exposed to $1 \%$ O with various concentrations of sulforaphane. Total cell lysates were prepared and subjected to western blot analysis. Representative results from three independent experiments are shown. $\beta$-actin was used as a loading control. N, normoxia.

$\left(1 \% \mathrm{O}_{2}\right.$ and $\left.5 \% \mathrm{CO}_{2}\right)$. Cell cultures were exposed to hypoxia and harvested at various time-points. Hypoxic conditions dramatically induced HIF-1 $\alpha$ protein expression in HCT116 and AGS cells (Fig. 1A). HIF-1 $\alpha$ protein induction was observed in cells $2 \mathrm{~h}$ after they were transferred to the hypoxic environment and become pronounced from the $2 \mathrm{~h}$ time-point through the $8 \mathrm{~h}$ time-point, reaching a maximum level at the $4 \mathrm{~h}$ and $6 \mathrm{~h}$ time-points; therefore, the $6 \mathrm{~h}$ time-point was selected for further experiments in HCT116 cells, while the $8 \mathrm{~h}$ time-point was selected for AGS cells.

The next study was performed to assess whether sulforaphane suppressed the observed responses to hypoxic conditions in HCT116 and AGS cells. Cells were pretreated with medium containing 12.5-100 $\mu \mathrm{M}$ sulforaphane for $1 \mathrm{~h}$ in normoxic conditions and transferred to a hypoxia chamber. Sulforaphane significantly inhibited HIF-1 $\alpha$ expression in HCT116 and AGS cells (Fig. 1B). Interestingly, low concentration of sulforaphane slightly induced hypoxia-induced HIF-1 $\alpha$ in HCT116 cells . Therefore, to investigate the effects of sulforaphane-induced cytotoxicity under normoxic and hypoxic conditions and determine whether cytotoxicity is responsible for suppression of HIF- $1 \alpha$ accumulation, cell viability was determined by MTT assay. No significant concentration-dependent reduction of viability was observed when HCT116 and AGS cells were treated with various concentrations of sulforaphane for 6 and $8 \mathrm{~h}$ under normoxic and hypoxic conditions (data not shown). These data indicated that the decrease in HIF-1 $\alpha$ abundance under normoxic and hypoxic conditions was not due to cell death.

Sulforaphane suppresses hypoxia-induced VEGF expression in HCT116 cells. VEGF is a target gene of HIF-1 that plays a crucial role in tumor angiogenesis. HIF-1 regulates VEGF expression at the transcriptional level (22). To determine whether sulforaphane inhibits VEGF expressions in HCT116 cells, VEGF transcript abundance was measured using an ELISA kit. Cells were incubated under hypoxic conditions with or without $12.5-50 \mu \mathrm{M}$ sulforaphane. After $24 \mathrm{~h}$ of treatment, cell culture media were collected and VEGF transcript abundance was measured. VEGF transcript was increased under hypoxic conditions. However, VEGF induction was decreased in a concentration-dependent manner by sulforaphane (Fig. 2A). Sulforaphane also inhibited hypoxia-related target protein expressions such as VEGF, heme oxygenase (HO)-1 and glucose transporter 1 (GLUT1) (Fig. 2B).

Sulforaphane affects the stability of HIF-1 $\alpha$ protein in HCT116 cells. To evaluate the mechanism by which sulforaphane inhibits HIF-1 $\alpha$ expression, HCT116 cells were exposed to hypoxic conditions to induce HIF-1 $\alpha$ protein expression. The exposure to hypoxic conditions was necessary because very little HIF-1 $\alpha$ is detectable under normoxic conditions due to rapid protein degradation. Cyclohexamide ( $\mathrm{CHX}$ ), a protein synthesis inhibitor, is widely used in protein stability studies. HCT116 cells were incubated for $6 \mathrm{~h}$ under hypoxic conditions and treated with $\mathrm{CHX}$ for $30 \mathrm{~min}$ in the presence or absence of $50 \mu \mathrm{M}$ sulforaphane. Cells were harvested at various timepoints and cell lysates were subjected to western blot analysis using anti-HIF-1 $\alpha$ antibodies. Under hypoxic conditions, the half-life of HIF-1 $\alpha$ was not longer than $1 \mathrm{~h}$ when the cells were treated with $\mathrm{CHX}$ alone (Fig. 3A). However, the half-life of HIF-1 $\alpha$ was $\sim 15$ min when the cells were treated with a combination of sulforaphane and CHX (Fig. 3B). These data revealed that sulforaphane reduced the half-life of HIF-1 $\alpha$ protein under hypoxic conditions, indicating that sulforaphane treatment regulates HIF-1 $\alpha$ expression by decreasing protein stability. These results demonstrate that sulforaphane affected hypoxia-induced HIF-1 $\alpha$ protein stability in HCT116 cells.

Next, to examine whether sulforaphane-induced HIF-1 $\alpha$ protein degradation is mediated by the proteasome degradation pathway, HCT116 cells were treated with proteasome inhibitor MG132 for $30 \mathrm{~min}$, followed by treatment with medium containing sulforaphane for $30 \mathrm{~min}$, after which the cells were exposed to hypoxic conditions for $6 \mathrm{~h}$, washed with PBS, and 


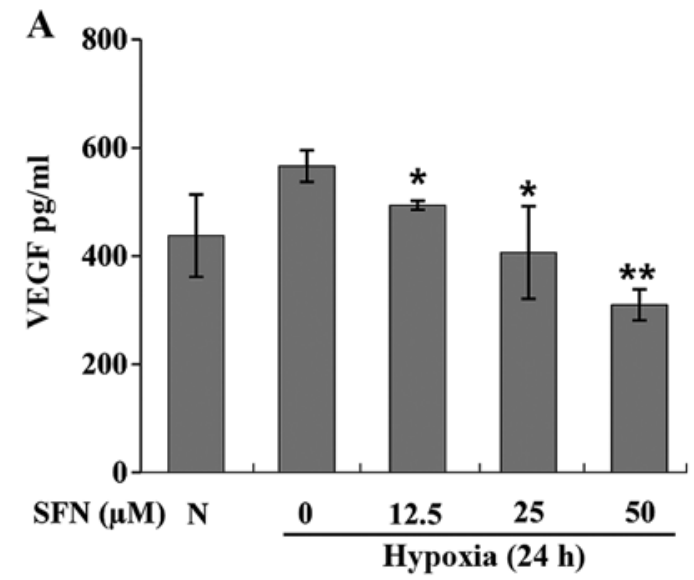

B

HCT116

Hypoxic condition (6 h)

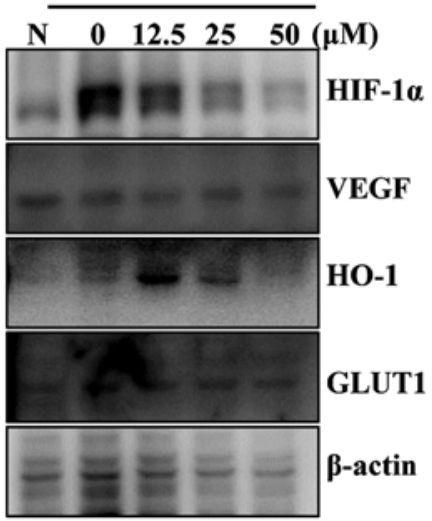

Figure 2. Effect of sulforaphane on VEGF secretion and hypoxia-related gene expression under hypoxic condition in HCT116 cells. (A) HCT116 cells were treated with various concentrations of sulforaphane (12.5-50 $\mu \mathrm{M})$ for $24 \mathrm{~h}$ under hypoxic conditions. The VEGF level in the culture media was determined by ELISA. The assays were performed in triplicate. Results are expressed as percentages of the vehicle-treated control level (mean \pm SD of three separate experiments). Significance was determined by Student's t-test ( $\mathrm{p}<0.05,{ }^{* *} \mathrm{p}<0.01$ vs. hypoxic conditions only). (B) HCT116 cells were exposed to $1 \% \mathrm{O}_{2}$ with various concentrations of sulforaphane. Total cell lysates were prepared and subjected to western blot analysis. $\beta$-actin was used as a loading control. N, normoxia. SFN, sulforaphane.

lysed inside the hypoxia chamber. Degradation of HIF-1 $\alpha$ protein induced by sulforaphane under hypoxic conditions was not completely prevented by MG132 (Fig. 3C and D). These data indicate that sulforaphane did not induce HIF-1 $\alpha$ protein degradation through the proteasome degradation pathway.

AKT and ERK signaling pathway is not involved in downregulation of HIF-1 $\alpha$ protein by sulforaphane under hypoxic conditions. Accumulating evidence has shown that multiple signaling pathways, particularly phosphatidylinositol 3-kinase (PI3K)/AKT and mitogen-activated protein kinase (MAPK)/ ERK pathways, are involved in hypoxia-induced HIF-1 $\alpha$ protein accumulation and downstream target gene expression (23). To determine whether sulforaphane inhibits hypoxiamediated activation of AKT, HCT116 cells were pretreated with various concentrations of sulforaphane for $1 \mathrm{~h}$ under normoxic conditions, followed by incubation for $6 \mathrm{~h}$ under hypoxic conditions, after which the cells were washed with
A
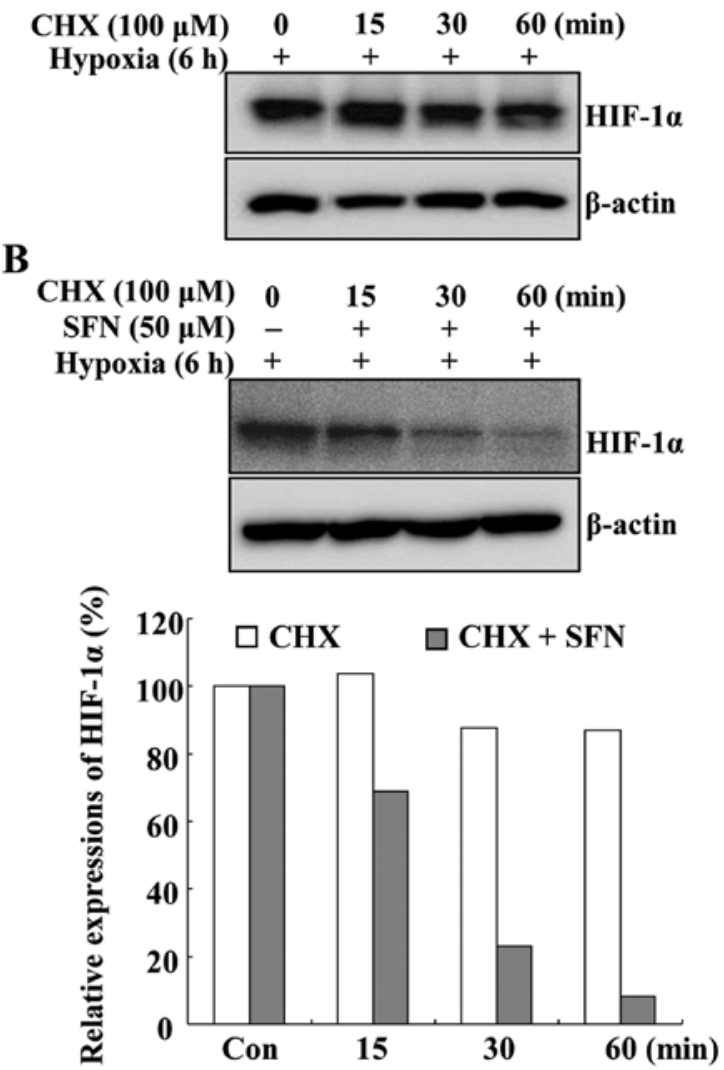

C

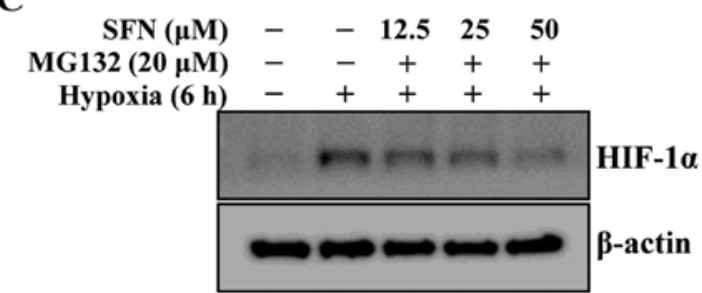

D

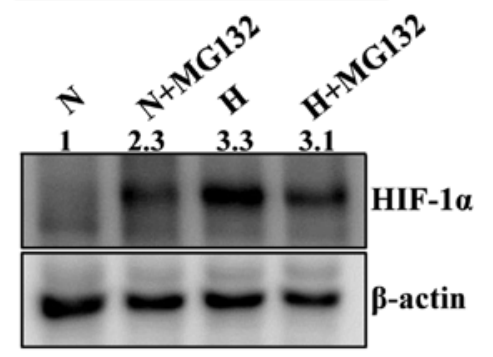

Figure 3. Effect of sulforaphane on HIF-1 $\alpha$ protein stability. (A) After HCT116 cells were exposed to hypoxic conditions for $6 \mathrm{~h}$ to induce HIF-1 $\alpha$, cells were treated with cycloheximide (CHX) for $30 \mathrm{~min}$, followed by treatment with (B) sulforaphane for various periods of time (15-60 min). All treatments were performed under hypoxic conditions. Relative expression of HIF-1 $\alpha$ as measured by fluorchem SP. Con, control; min, minutes. (C) Cells were exposed to $1 \% \mathrm{O}_{2}$ and treated with various concentrations of sulforaphane $(12.5-50 \mu \mathrm{M})$ for $6 \mathrm{~h}$ with or without $20 \mu \mathrm{M}$ MG132. Total cell lysates were prepared and subjected to western blot analysis. (D) HCT116 cells were exposed to hypoxic or normoxic conditions for $6 \mathrm{~h}$ with or without $20 \mu \mathrm{M}$ MG132. Total cell lysates were prepared and subjected to western blot analysis. Representative results from three independent experiments are shown. $\beta$-actin was used as a loading control. SFN, sulforaphane. N, normoxia. H, hypoxia.

PBS and lysed inside the hypoxia chamber. Sulforaphane did not inhibit phosphorylation of AKT and ERK under hypoxic conditions (Fig. 4A). Interestingly, hypoxia-induced HIF-1 $\alpha$ 
A
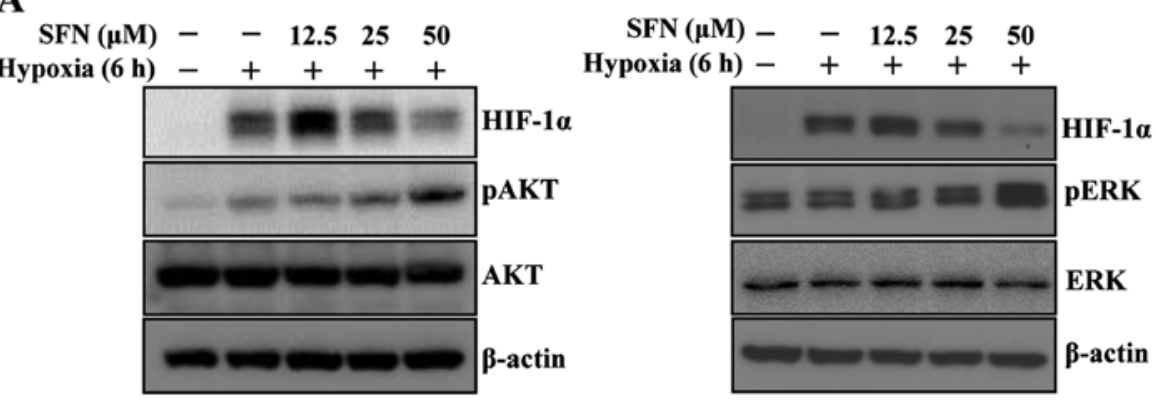

B
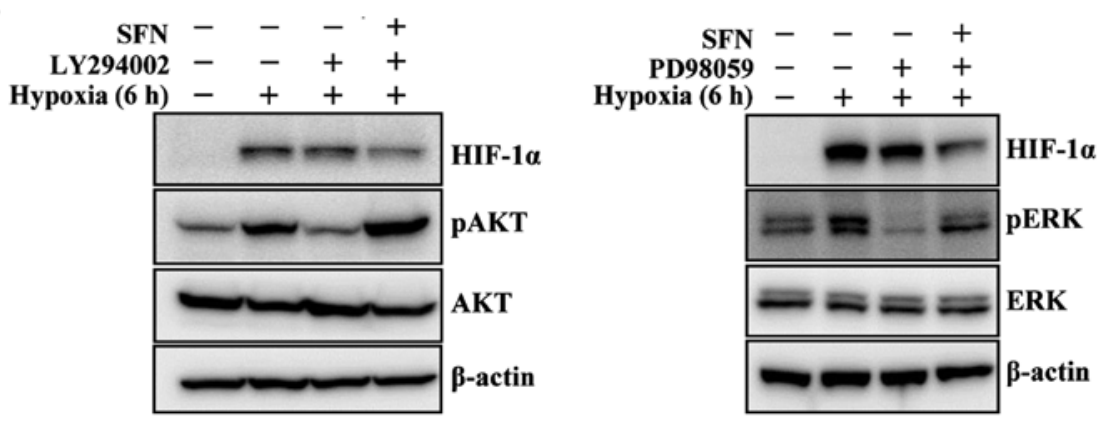

Figure 4. Role of PI3K and ERK in HIF-1 $\alpha$ accumulation induced by sulforaphane under hypoxic conditions. (A) Cells were exposed to $1 \% \mathrm{O}_{2}$ and treated with various concentrations of sulforaphane (12.5-50 $\mu \mathrm{M})$ for $6 \mathrm{~h}$. (B) Cells were exposed to $1 \% \mathrm{O}_{2}$ in combination with sulforaphane (50 $\left.\mu \mathrm{M}\right)$ and LY294002 or PD98059, specific inhibitors of AKT and ERK (both at a concentration of $50 \mu \mathrm{M}$ ), respectively, for $6 \mathrm{~h}$. Total cell lysates were prepared and subjected to western blot analysis. Representative results from three independent experiments are shown. $\beta$-actin was used as a loading control. SFN, sulforaphane.

A

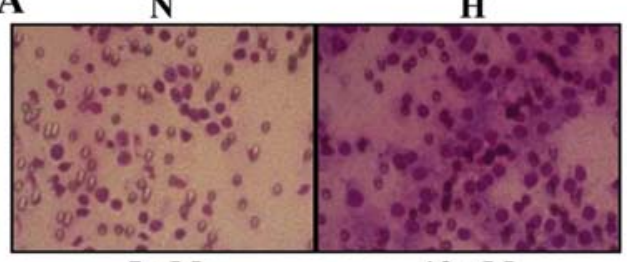

$5 \mu \mathrm{M}$

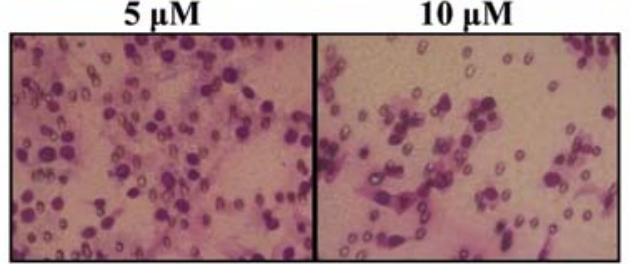

B

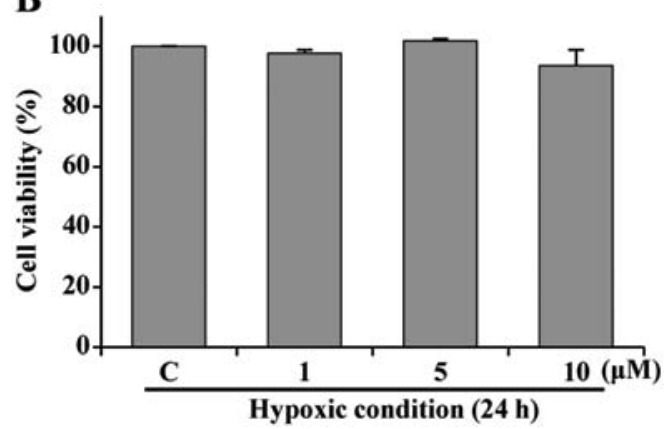

Figure 5. Sulforaphane inhibits hypoxia-induced HCT116 cell migration. (A) For the migration assay, cells were placed in the upper chamber inserts with the indicated concentrations of sulforaphane and allowed to migrate for $24 \mathrm{~h}$. Membranes containing migrated cells were stained. Ten random fields from each experiment were counted under a microscope. The bars represent $100 \mu \mathrm{m}$. Representative results from three independent experiments are shown. N, normoxia; $\mathrm{H}$, hypoxia. (B) HCT116 cells were exposed to various concentrations of sulforaphane $(1-10 \mu \mathrm{M})$ for $24 \mathrm{~h}$ under hypoxic conditions. Cell viability was determined by MTT assay. The results are presented as the mean \pm SD of three independent experiments. C, control. was slightly increased by low concentration of sulforaphane. To determine whether sulforaphane activates AKT and ERK, cells were exposed to PI3K inhibitor LY294002 and ERK inhibitor PD98059. LY294002 and PD98059 significantly decreased the elevated levels of HIF-1 $\alpha$, pAKT, and pERK protein induced by hypoxic conditions (Fig. 4B). However, combination of the inhibitors with sulforaphane dramatically restored pAKT and pERK expression under hypoxic conditions (Fig. 4B). These results show that the decrease in HIF-1 $\alpha$ expression produced by sulforaphane in HCT116 cells under hypoxic conditions is not mediated by regulation of PI3K and ERK pathways.

Sulforaphane inhibits hypoxia-induced migration. Hypoxic conditions enhance metastasis of several types of cancer cells, including colon and breast cancer cells. In vitro migration experiments were performed to determine whether sulforaphane inhibits HCT116 cell motility. HCT116 cells were treated with sulforaphane under normoxic and hypoxic conditions. As shown in Fig. 5A, there was little cell migration under normoxic conditions. However, cell migration increased under hypoxic conditions. Treatment with 5 and $10 \mu \mathrm{M}$ sulforaphane suppressed migration activity. Sulforaphane was not cytotoxic at concentrations of 5 and $10 \mu \mathrm{M}$ under hypoxic conditions (Fig. 5B). These results indicate that treatment with sulforaphane suppressed hypoxia-induced HCT116 cell migration.

\section{Discussion}

Phytochemicals are important cancer prevention tools. The chemopreventive mechanisms of many phytochemicals, including sulforaphane, are not well understood. Sulforaphane induces phase 2 antioxidant enzymes such as glutathione 
transferases, $\mathrm{NAD}(\mathrm{P}) \mathrm{H}: q u i n o n e ~ r e d u c t a s e$, epoxide hydrolase, heme oxygenase, and UDP-glucuronosyltranferase, which play important roles in detoxification of electrophiles and protect against carcinogenesis and mutagenesis (11). During the last decade, many studies on sulforaphane as a chemopreventive agent in various cancer cell lines were released. However, the mechanism by which sulforaphane inhibits HIF-1 $\alpha$ expression under hypoxic conditions is controversial and not well understood. In this study, we evaluated inhibition of HIF-1 $\alpha$ and VEGF expression under hypoxic conditions by sulforaphane in human colon cancer cells.

Hypoxic conditions rapidly induced expression of HIF-1 $\alpha$ in HCT116 human colon cancer cells and AGS human gastric cancer cells (Fig. 1A). However, sulforaphane inhibited HIF-1 $\alpha$ expression concentration-dependently in both cell lines (Fig. 1B). Yao et al showed similar results in human tongue and prostate cancer cells (7). VEGF is a key protein downstream of HIF-1 under hypoxic conditions. Induction of VEGF expression under hypoxic conditions causes sprouting of new blood vessels from existing endothelia, which is essential for wound repair, organ regeneration, embryonic vascular system development, and a variety of pathological conditions, including tumor angiogenesis and metastasis of various solid tumors $(24,25)$. Treatment with sulforaphane under hypoxic conditions inhibited VEGF activity in HCT116 cells (Fig. 2A). Sulforaphane also slightly suppressed HIF-1-regulated gene expressions such as VEGF, HO-1 and GLUT1 (Fig. 2B).

Degradation of HIF-1 $\alpha$ protein under normoxic conditions is tightly regulated by ubiquitination and the $26 \mathrm{~S}$ proteasomal degradation system. Under hypoxic conditions, ubiquitination and degradation of HIF-1 $\alpha$ protein is suppressed, leading to stabilization and accumulation of HIF-1 $\alpha$ protein and nuclear translocation (26). In this study, expression of HIF-1 $\alpha$ under hypoxic conditions was inhibited by sulforaphane in HCT116 cells (Fig. 2B). Moreover, sulforaphane significantly shortened the half-life of hypoxia-induced HIF-1 $\alpha$ protein (Fig. 3B). However, inhibition of hypoxia-induced HIF-1 $\alpha$ protein accumulation by sulforaphane was not abolished in the presence of MG132, a potent inhibitor of the 26S proteasome (Fig. 3C). These results were similar to those reported by others previously (7). There are several possible explanations for these results. One possible explanation is that the lysosome pathway is involved in degradation of HIF-1 $\alpha$ following sulforaphane treatment under hypoxic conditions (27). Treatment with lysosomal inhibitors, including bafilomycin A1 and chloroquine, induces HIF-1 $\alpha$ expression and activity, while hypoxic conditions induce chaperone-mediated autophagy and lysosomal biogenesis in cancer cells (28). In addition, some studies have reported that treatment with sulforaphane strongly enhanced the proteasome pathway (29-31). Jung et al reported that hypoxia-induced HIF-1 $\alpha$ expression was inhibited by rhapontigenin through interaction with von Hippel-Lindau in PC3 cells (32). Degradation of HIF-1 $\alpha$ induced by sulforaphane under hypoxic conditions did not involve the $26 \mathrm{~S}$ proteasome pathway in our culture system. Further studies are required to determine the mechanisms by which HIF-1 $\alpha$ degradation induced by sulforaphane under hypoxic conditions exerts potent anti-angiogenic activity.

Accumulating evidence indicates that hypoxic conditions activate several signaling pathways, including PI3K/AKT, glycogen synthase kinase 3 beta (GSK-3 3 ), and ERK $(4,5)$. In this study, hypoxic conditions induced PI3K/AKT and ERK in HCT116 cells (Fig. 4A). Treatment of HCT116 cells with PI3K/AKT inhibitor LY294002 and ERK inhibitor PD98059 confirmed that both pathways are important for hypoxia-mediated HIF-1 $\alpha$ stabilization. However, treatment with sulforaphane under hypoxic conditions induced pAKT and pERK, even in the presence of LY294002 and PD98059 (Fig. 4B). Several studies in cancer cells have shown that sulforaphane is an Nrf2 activator $(8,33,34)$. Treatment with sulforaphane strongly and concentration-dependently induced expression of Nrf2 under hypoxic conditions in our culture system (data not shown). Treatment with sulforaphane causes autophagy in various human cancer cell lines, including colon, pancreas, and prostate cancer cells $(9,35,36)$. Induction of PI3K and ERK pathway activity could be possible when sulforaphane causes autophagy under hypoxic conditions. However, more studies are necessary to determine the effects of sulforaphane on PI3K and ERK pathways.

Accumulating evidence in solid tumors has shown that HIF-1 $\alpha$ overexpression, either as a result of intratumoral hypoxia or genetic alterations, activates gene transcription, and the protein products contribute to basement membrane migration and invasion $(25,37,38)$. In this study, treatment with sulforaphane inhibited hypoxia-induced migration by HCT116 cells (Fig. 5A). The sulforaphane concentrations tested in the migration assay did not affect cell viability under hypoxic conditions (Fig. 5B). However, extensive studies are needed to identify the genes that are directly or indirectly involved in sulforaphane-regulated cancer cell migration and metastasis in response to hypoxic conditions.

In this study, we showed that sulforaphane inhibited HIF-1 $\alpha$ protein expression in HCT116 and AGS cells under hypoxic conditions. In addition, sulforaphane treatment inhibited hypoxia-induced VEGF expression in HCT116 cells. Inhibition of HIF-1 $\alpha$ protein expression by sulforaphane was associated with destabilization of HIF-1 $\alpha$ protein and prevention of HIF-1 $\alpha$ target gene activation. Sulforaphane also inhibited hypoxia-induced cell migration. These data suggest that sulforaphane may inhibit human colon cancer angiogenesis and migration by inhibiting HIF-1 $\alpha$ and VEGF expression under hypoxic conditions. Taken together, these results indicate that sulforaphane might be a new potent chemopreventive agent against human cancer cells.

\section{Acknowledgements}

This study was financially supported by the 2015 Post-doc Development Program of Pusan National University.

\section{References}

1. Semenza GL: Hypoxia and human disease - and the Journal of Molecular Medicine. J Mol Med Berl 85: 1293-1294, 2007.

2. Ferrara N, Gerber HP and LeCouter J: The biology of VEGF and its receptors. Nat Med 9: 669-676, 2003.

3. Semenza GL: Hypoxia-inducible factor 1 (HIF-1) pathway. Sci STKE 2007: cm8, 2007.

4. Mirzoeva S, Kim ND, Chiu K, Franzen CA, Bergan RC and Pelling JC: Inhibition of HIF-1 alpha and VEGF expression by the chemopreventive bioflavonoid apigenin is accompanied by Akt inhibition in human prostate carcinoma PC3-M cells. Mol Carcinog 47: 686-700, 2008. 
5. Kim DH, Hossain MA, Kim MY, Kim JA, Yoon JH, Suh HS Kim GY, Choi YH, Chung HY and Kim ND: A novel resveratrol analogue, HS-1793, inhibits hypoxia-induced HIF-1 $\alpha$ and VEGF expression, and migration in human prostate cancer cells. Int $\mathrm{J}$ Oncol 43: 1915-1924, 2013.

6. Chen MC, Lee CF, Huang WH and Chou TC: Magnolol suppresses hypoxia-induced angiogenesis via inhibition of HIF-1 $\alpha$ /VEGF signaling pathway in human bladder cancer cells. Biochem Pharmacol 85: 1278-1287, 2013.

7. Yao H, Wang H, Zhang Z, Jiang BH, Luo J and Shi X: Sulforaphane inhibited expression of hypoxia-inducible factorlalpha in human tongue squamous cancer cells and prostate cancer cells. Int J Cancer 123: 1255-1261, 2008.

8. Jo GH, Kim GY, Kim WJ, Park KY and Choi YH: Sulforaphane induces apoptosis in T24 human urinary bladder cancer cells through a reactive oxygen species-mediated mitochondrial pathway: The involvement of endoplasmic reticulum stress and the Nrf2 signaling pathway. Int J Oncol 45: 1497-1506, 2014.

9. Wang M, Zhu JY, Chen S, Qing Y, Wu D, Lin YM, Luo JZ, Han W and Li YQ: Effects of co-treatment with sulforaphane and autophagy modulators on uridine 5'-diphospho-glucuronosyltransferase 1A isoforms and cytochrome $\mathrm{P} 450$ 3A4 expression in Caco-2 human colon cancer cells. Oncol Lett 8: 2407-2416, 2014.

10. Juge N, Mithen RF and Traka M: Molecular basis for chemoprevention by sulforaphane: A comprehensive review. Cell Mol Life Sci 64: 1105-1127, 2007.

11. Fahey JW and Talalay P: Antioxidant functions of sulforaphane: A potent inducer of Phase II detoxication enzymes. Food Chem Toxicol 37: 973-979, 1999.

12. Kraft AD, Johnson DA and Johnson JA: Nuclear factor E2-related factor 2-dependent antioxidant response element activation by tert-butylhydroquinone and sulforaphane occurring preferentially in astrocytes conditions neurons against oxidative insult. J Neurosci 24: 1101-1112, 2004.

13. Boddupalli S, Mein JR, Lakkanna S and James DR: Induction of phase 2 antioxidant enzymes by broccoli sulforaphane: Perspectives in maintaining the antioxidant activity of vitamins A, C, and E. Front Genet 3: 7, 2012.

14. Chen X, Liu J and Chen SY: Sulforaphane protects against ethanol-induced oxidative stress and apoptosis in neural crest cells by the induction of Nrf2-mediated antioxidant response. $\mathrm{Br}$ J Pharmacol 169: 437-448, 2013.

15. Gamet-Payrastre L, Li P, Lumeau S, Cassar G, Dupont MA, Chevolleau S, Gasc N, Tulliez J and Tercé F: Sulforaphane, a naturally occurring isothiocyanate, induces cell cycle arrest and apoptosis in HT29 human colon cancer cells. Cancer Res 60: $1426-1433,2000$

16. Pledgie-Tracy A, Sobolewski MD and Davidson NE: Sulforaphane induces cell type-specific apoptosis in human breast cancer cell lines. Mol Cancer Ther 6: 1013-1021, 2007.

17. Jeon YK, Yoo DR, Jang YH, Jang SY and Nam MJ: Sulforaphane induces apoptosis in human hepatic cancer cells through inhibition of 6-phosphofructo-2-kinase/fructose-2,6-biphosphatase4 mediated by hypoxia inducible factor-1-dependent pathway. Biochim Biophys Acta 1814: 1340-1348, 2011.

18. Parnaud G, Li P, Cassar G, Rouimi P, Tulliez J, Combaret L and Gamet-Payrastre L: Mechanism of sulforaphane-induced cell cycle arrest and apoptosis in human colon cancer cells. Nutr Cancer 48: 198-206, 2004.

19. Wang M, Chen S, Wang S, Sun D, Chen J, Li Y, Han W, Yang X and Gao HQ: Effects of phytochemicals sulforaphane on uridine diphosphate-glucuronosyltransferase expression as well as cellcycle arrest and apoptosis in human colon cancer Caco-2 cells. Chin J Physiol 55: 134-144, 2012.

20. Chung FL, Conaway CC, Rao CV and Reddy BS: Chemoprevention of colonic aberrant crypt foci in Fischer rats by sulforaphane and phenethyl isothiocyanate. Carcinogenesis 21 : 2287-2291, 2000.

21. Hu R, Khor TO, Shen G, Jeong WS, Hebbar V, Chen C, Xu C, Reddy B, Chada K and Kong AN: Cancer chemoprevention of intestinal polyposis in ApcMin/+ mice by sulforaphane, a natural product derived from cruciferous vegetable. Carcinogenesis 27 : 2038-2046, 2006
22. Semenza GL: Regulation of hypoxia-induced angiogenesis: A chaperone escorts VEGF to the dance. J Clin Invest 108: 39-40, 2001.

23. Semenza GL: Involvement of hypoxia-inducible factor 1 in human cancer. Intern Med 41: 79-83, 2002.

24. Denes V, Lakk M, Makarovskiy A, Jakso P, Szappanos S, Graf L, Mandel L, Karadi I and Geck P: Metastasis blood test by flow cytometry: In vivo cancer spheroids and the role of hypoxia. Int J Cancer 136: 1528-1536, 2015.

25. Liu ZJ, Semenza GL and Zhang HF: Hypoxia-inducible factor 1 and breast cancer metastasis. J Zhejiang Univ Sci B 16: 32-43, 2015.

26. Pugh CW and Ratcliffe PJ: The von Hippel-Lindau tumor suppressor, hypoxia-inducible factor-1 (HIF-1) degradation, and cancer pathogenesis. Semin Cancer Biol 13: 83-89, 2003.

27 Rudolf E and Cervinka M: Sulforaphane induces cytotoxicity and lysosome- and mitochondria-dependent cell death in colon cancer cells with deleted p53. Toxicol In Vitro 25: 1302-1309, 2011.

28. Hubbi ME, Hu H, Kshitiz, Ahmed I, Levchenko A and Semenza GL: Chaperone-mediated autophagy targets hypoxiainducible factor- $1 \alpha$ (HIF-1 $\alpha)$ for lysosomal degradation. J Biol Chem 288: 10703-10714, 2013

29. Kwak MK, Cho JM, Huang B, Shin S and Kensler TW: Role of increased expression of the proteasome in the protective effects of sulforaphane against hydrogen peroxide-mediated cytotoxicity in murine neuroblastoma cells. Free Radic Biol Med 43: 809-817, 2007.

30. Gan N, Wu YC, Brunet M, Garrido C, Chung FL, Dai C and Mi L: Sulforaphane activates heat shock response and enhances proteasome activity through up-regulation of Hsp27. J Biol Chem 285: 35528-35536, 2010.

31. Balasubramanian S, Chew YC and Eckert RL: Sulforaphane suppresses polycomb group protein level via a proteasomedependent mechanism in skin cancer cells. Mol Pharmacol 80: 870-878, 2011.

32. Jung DB, Lee HJ, Jeong SJ, Lee HJ, Lee EO, Kim YC, Ahn KS, Chen CY and Kim SH: Rhapontigenin inhibited hypoxia inducible factor 1 alpha accumulation and angiogenesis in hypoxic PC-3 prostate cancer cells. Biol Pharm Bull 34: 850-855, 2011.

33. Kensler TW, Egner PA, Agyeman AS, Visvanathan K, Groopman JD, Chen JG, Chen TY, Fahey JW and Talalay P: Keap1-nrf2 signaling: A target for cancer prevention by sulforaphane. Top Curr Chem 329: 163-177, 2013.

34. Zhang C, Su ZY, Khor TO, Shu L and Kong AN: Sulforaphane enhances Nrf2 expression in prostate cancer TRAMP C1 cells through epigenetic regulation. Biochem Pharmacol 85: 13981404,2013

35. Herman-Antosiewicz A, Johnson DE and Singh SV: Sulforaphane causes autophagy to inhibit release of cytochrome $c$ and apoptosis in human prostate cancer cells. Cancer Res 66: 58285835,2006

36. Naumann P, Fortunato F, Zentgraf H, Büchler MW, Herr I and Werner J: Autophagy and cell death signaling following dietary sulforaphane act independently of each other and require oxidative stress in pancreatic cancer. Int J Oncol 39: 101-109, 2011.

37. Zhang J, Cao J, Ma S, Dong R, Meng W, Ying M, Weng Q, Chen Z, Ma J, Fang Q, et al: Tumor hypoxia enhances non-small cell lung cancer metastasis by selectively promoting macrophage M2 polarization through the activation of ERK signaling. Oncotarget 5: 9664-9677, 2014.

38. Matsuo Y, Ding Q, Desaki R, Maemura K, Mataki Y, Shinchi H, Natsugoe $S$ and Takao S: Hypoxia inducible factor-1 alpha plays a pivotal role in hepatic metastasis of pancreatic cancer: An immunohistochemical study. J Hepatobiliary Pancreat Sci 21: 105-112, 2014. 